\title{
Antiproteases and Down's syndrome in an Australian population*
}

\author{
H MCPHEE, R ANANTHAKRISHNAN, $\uparrow$ AND L I TAFT
}

From the Department of Genetics, University of Melbourne, Parkville, Victoria 3052; and Department of Pathology, Mercy Maternity Hospital, Melbourne, Victoria 3000, Australia

SUMMARY $\alpha_{1}$-antitrypsin phenotypes and $\alpha_{2}$-macroglobulin concentrations were determined for an Australian population of 286 Down's syndrome patients, 296 newborn babies, and 193 patients with non-specific mental retardation. There was no significant difference between the groups in the distribution of the phenotypes or level of heterozygosity. The phenotypic frequencies were 89.5\% PiMM, 8.0\% PiMS, and 1.0\% PiMZ among controls. The mean $\alpha_{2}$-macroglobulin concentrations were investigated and it was shown that PiMZ phenotypes had a higher concentration, $2.67 \pm 0.27 \mathrm{~g} / 1$ (newborns) and $2.74 \pm 0.32 \mathrm{~g} / 1$ (Down's syndrome), in comparison with PiMS, PiSS, and PiMM.

The increased frequency of heterozygotes for $\alpha_{1}$-AT phenotypes among mothers of children with chromosomal aberrations noted by Aarskog and Fagerhol ${ }^{1}$ suggested a relationship between $\alpha_{1}$-AT phenotypes and chromosomal abnormalities. This observation has been extended by Kueppers $e t a l^{2}$ who noted an excess of heterozygotes in the combined parental group as well as among patients with chromosomal abnormalities. Similarly, Fineman et $a l^{3}$ noted an increased frequency of heterozygotes among Down's syndrome patients in the older mothers groups; distribution of $\alpha_{1}$-AT phenotypes among parents were not determined. However, Arnaud et $\mathrm{al}^{4}$ were unable to observe any significant differences in the distribution of $\alpha_{1}$-AT phenotypes between Down's syndrome patients and controls.

In view of these contradictions, we report the results of investigations on $\alpha_{1}$-antitrypsin phenotypes as well as quantification of $\alpha_{2}$-macroglobulin in Down's syndrome, non-specific mental retardation, and in controls for an Australian population.

\section{Materials and methods}

$\alpha_{1}$-antitrypsin was phenotyped by isoelectric focusing in thin layers of polyacrylamide gels using the method of Kueppers, ${ }^{5}$ with minor modifications,

\footnotetext{
*Supported in part by a grant from the Triple $\mathbf{R}$ foundation and the Apex foundation for research into mental retardation. tR Ananthakrishnan now deceased.

Received for publication 11 July 1979
}

using LKB ampholines in the $\mathrm{pH}$ range of 4 to 6 . The gel was prerun at a constant $25 \mathrm{~mA}$ for one hour. On completion of the run, the protein bands were precipitated in $10 \%$ trichloracetic acid overnight and the gel washed in two rinses of distilled water. Proteins were stained using $0.25 \%$ amido black in $7 \%$ acetic acid and destained in $7 \%$ acetic acid. Rare phenotypes were identified by comparison with standards obtained through the courtesy of $\mathrm{Dr} M$ Fagerhol, Oslo, Norway.

QUANTIFICATION OF $\alpha_{1}-$ AT AND $\alpha_{2}-$ MG

Radial immunodiffusion was used to determine $\alpha_{1}$-antitrypsin and $\alpha_{2}$-macroglobulin concentrations in sera. The antisera were commercially available from Kallestad and Berhingwerke standard plasmas of known $\alpha_{1}$-antitrypsin and $\alpha_{2}$-macroglobulin concentrations $(\mathrm{g} / \mathrm{l})$ were used as controls. Samples for $\alpha_{2}$-macroglobulin levels were diluted $1: 2$ and samples for $\alpha_{1}$-antitrypsin levels were diluted in accordance with their phenotype. $\mathrm{ZZ}$ sera were used undiluted, SS, SZ, and MZ sera were diluted $1: 10$, and all others were diluted $1: 20$.

The plates were left at $4^{\circ} \mathrm{C}$ for 48 hours in the case of $\alpha_{1}-\mathrm{AT}$ and 72 hours for $\alpha_{2}-\mathrm{MG}$ and the resulting precipitin ring diameters were measured. $\stackrel{\infty}{?}$ A standard graph was constructed, using the control 0 sera of concentration $(\mathrm{g} / \mathrm{l})$ vs the squares of the diameter of the precipitin ring. Results for the other samples were read off the graph using the same technique. 
TABLE 1 Phenotypic distribution of $\alpha_{1}-A T$ in Australian populations

\begin{tabular}{|c|c|c|c|c|c|c|c|c|c|c|}
\hline Samples & $M$ & $M S$ & $M Z$ & $G M$ & $F M$ & $F F$ & $S S$ & $S Z$ & Others & Total \\
\hline $\begin{array}{l}\text { Cord blood } \\
\text { Observed } \\
\text { Expected } \\
\chi_{1}^{2} \\
\text { Down's }\end{array}$ & $\begin{array}{l}89.5 \% \\
265 \\
252.9 \\
0.60\end{array}$ & $\begin{array}{l}8 \cdot 0 \% \\
21 \\
25 \cdot 6 \\
0 \cdot 80\end{array}$ & $1.0 \%$ & $1.0 \%$ & - & - & $1.0 \%$ & - & $1 \mathrm{MN}$ & 296 \\
\hline $\begin{array}{l}\text { syndrome } \\
\text { Observed } \\
\text { Expected } \\
\chi_{1}^{2} \\
\text { Non-specific }\end{array}$ & $\begin{array}{c}88 \cdot 8 \% \\
254 \\
269 \cdot 4 \\
0.09\end{array}$ & $\begin{array}{l}8 \cdot 7 \% \\
25 \\
23 \cdot 7 \\
0 \cdot 007\end{array}$ & $1.4 \%$ & $0.35 \%$ & $0.35 \%$ & $0.35 \%$ & - & - & & 286 \\
\hline $\begin{array}{l}\text { retardation } \\
\text { Observed } \\
\text { Expected } \\
\chi_{1}^{2}\end{array}$ & $\begin{array}{c}89.6 \% \\
173 \\
181.4 \\
0.4\end{array}$ & $\begin{array}{l}8 \cdot 7 \% \\
15 \\
16 \cdot 0 \\
0.005\end{array}$ & $1.2 \%$ & - & - & - & $0.5 \%$ & $0.5 \%$ & $1 \mathrm{MP}$ & 193 \\
\hline $\begin{array}{l}\text { Pool } \\
\text { Observed } \\
\text { Expected } \\
\chi_{1}^{2}\end{array}$ & $\begin{array}{l}89 \cdot 3 \% \\
692 \\
728 \cdot 5 \\
1 \cdot 8\end{array}$ & $\begin{array}{l}9.0 \% \\
61 \\
65 \cdot 6 \\
0.30\end{array}$ & $\begin{array}{l}1 \cdot 2 \% \\
9 \\
8 \cdot 7 \\
0 \cdot 01\end{array}$ & $0.5 \%$ & $0.1 \%$ & $0.1 \%$ & $0.5 \%$ & $0.1 \%$ & $1 \mathrm{MN} 1 \mathrm{MP}$ & 775 \\
\hline
\end{tabular}

\section{SAMPLES}

Cord blood samples had been previously collected from the Mercy Maternity Hospital, Melbourne. Sera from patients with Down's syndrome and non-specific mental retardation were obtained as has been described by Ball et $a l^{6}$ and Brackenridge et al. ${ }^{7}$

\section{Results}

The distribution of the $\alpha_{1}-\mathrm{AT}$ phenotypes is given in table 1. It is obvious that there is no significant difference in the frequency of the common phenotypes MM and MS in the three groups. The distribution of the two phenotypes MM and MS are found to be in Hardy-Weinberg equilibrium. The allele frequencies of $\mathbf{P i}^{\mathrm{m}}, \mathbf{P i}^{\mathrm{s}}$, and $\mathbf{P i}^{\mathrm{z}}$ are given in table 2. This table shows the differences in these three alleles between Australian, British, and American populations. Although the $\mathrm{z}$ allele frequency is considerably higher in the American population, the $s$ allele frequency is lower. The allele frequencies for the Australian and British populations are very similar. The only difference in the distribution of $\alpha_{1}$-AT phenotypes is the occurrence of rare phenotypes GM, FM, and FF at a frequency of $1.05 \%$ among Down's syndrome patients. There was no difference in the frequency of

TABLE 2 Distribution of Pi allele frequencies in selected populations

\begin{tabular}{|c|c|c|c|}
\hline \multirow[t]{2}{*}{ Allele } & \multicolumn{3}{|l|}{ Frequency } \\
\hline & $\begin{array}{l}\text { Australian } \\
\text { (this study) }\end{array}$ & British $^{8}$ & American ${ }^{9}$ \\
\hline $\begin{array}{l}\mathbf{P i}^{\mathbf{l n}} \\
\mathbf{P i}^{\mathbf{S}} \\
\mathbf{P i}^{\mathrm{z}}\end{array}$ & $\begin{array}{l}0.940 \\
0.045 \\
0.006\end{array}$ & $\begin{array}{l}0.950 \\
0.043 \\
0.007\end{array}$ & $\begin{array}{l}0.930 \\
0.034 \\
0.0186\end{array}$ \\
\hline
\end{tabular}

TABLE 3 Relationship between $a_{1}-A T$ phenotypes and $a_{2}-M G$ concentration

\begin{tabular}{llcc}
\hline Phenotype & Source & No & $\begin{array}{c}\alpha_{2}-M G \\
\text { concentration }(g / l)\end{array}$ \\
\hline MM & Cord blood & 60 & $2 \cdot 96 \pm 0 \cdot 56$ \\
MM & Down's syndrome & 39 & $2 \cdot 25 \pm 0 \cdot 50$ \\
MM & Adult blood donors & 39 & $1 \cdot 74 \pm 0 \cdot 41$ \\
MS & Cord blood & 18 & $2 \cdot 15 \pm 0 \cdot 45$ \\
MS & Down's syndrome & 8 & $2 \cdot 13 \pm 0 \cdot 56$ \\
MZ & Newborns & 3 & $2 \cdot 67 \pm 0 \cdot 27$ \\
MZ & Down's syndrome & 3 & $2 \cdot 75 \pm 0 \cdot 32$ \\
ZZ & Liver patients & 10 & $2 \cdot 08 \pm 0 \cdot 28$ \\
& (children) & & \\
\hline
\end{tabular}

total heterozygosity $(11.5 \%$ among Down's syndrome, $10.9 \%$ among non-specific mental retardation patients, and $11 \%$ among newborn infants).

Table 3 shows the results of quantitative estimation of $\alpha_{2}$-macroglobulin and $\alpha_{1}-\mathrm{AT}$ in newborn children and in Down's syndrome. The mean $\alpha_{1}-\mathrm{AT}$ concentration among newborn children was $2.84 \pm 0.88 \mathrm{~g} / \mathrm{l}$, while that of the Down's syndrome group was $3.06 \pm 0.46 \mathrm{~g} / \mathrm{l}$. In contrast to this, however, the mean concentration of the $\alpha_{2}$-macroglobulin was $2.96 \pm 0.56 \mathrm{~g} / 1$ among newborn children, while it was $2 \cdot 25 \pm 0.50 \mathrm{~g} / 1$ among Down's syndrome patients.

\section{Discussion}

The allele frequencies found in this Australian pooled sample compare very favourably with those of $\mathrm{Cook}^{8}$ for a British population. The allelic frequencies for Australian and British populations are much more similar than those of Rynbrandt et $a l^{9}$ for an American population. This is not surprising when you consider the ethnic backgrounds of the countries involved.

Earlier investigations had shown an increased 
frequency of heterozygotes among patients with sex chromosome mosaicism. For example, Aarskog and Fagerhol $^{1}$ detected two MS among 14 patients $(14 \%)$ which was higher than the 8 to $9 \%$ frequency of MS reported for Caucasian populations. However, these authors were unable to decide whether the increased frequency was among the paternal or maternal group or both. Kueppers $e t a l^{2}$ noted an increased frequency of heterozygotes among 21 patients with sex chromosome mosaicism (23.8\%); this increase was noted in both the maternal and paternal group. Fineman et $a l^{3}$ observed that in Down's syndrome patients whose mothers were 35 and over at the time of their birth, there was an increased frequency of heterozygotes for $\alpha_{1}-\mathrm{AT}$ phenotypes.

The lack of an increase in heterozygosity for $\alpha_{1}-\mathrm{AT}$ variants in the current study contradicts the findings of Fineman et $a .^{3}$ It may be argued that the discrepancy could be attributed to the lack of information regarding maternal age. This, however, is unlikely to provide a satisfactory explanation since a major proportion of Down's syndrome children are found among progeny of older mothers, while those of younger mothers constitute only a small proportion of the total. ${ }^{10}$ Similarly, Arnaud et $a l^{4}$ were unable to find an increased frequency of $\alpha_{1}$-AT heterozygotes among Down's syndrome children. Also, our sample sizes are considerably larger than those of Fineman et $a l,{ }^{3} 286$ as against 60 Down's syndrome patients.

Evans et al $^{11}$ reported differences in the relative concentrations of proteins in the electrophoretic bands 4 and 6, numbering being in order of decreasing anodal mobility. Among newborn children, the relative anodal bands, notably band 4 , are more intense, the pattern being reversed after birth. The control population consisted of newborn children and a similar pattern was observed, even though isoelectric focusing rather than starch gel electrophoresis was used. These changes may represent developmental changes in the relative activities of multiple molecular forms of $\alpha_{1}$-antitrypsin. The significance of these changes is yet to be elucidated.

$\alpha_{2}$-macroglobulin, one of the antiproteases found in comparable concentrations in human serum, is capable of inhibiting trypsin in common with $\alpha_{1}$-AT. Therefore, it seemed worthwhile to study a wide variety of proteolytic enzymes, including the $\alpha_{2}$-macroglobulin concentration, among Down's syndrome patients as well as to investigate the possible influence of $\alpha_{1}$-AT phenotypes on $\alpha_{2}$-MG concentrations. $\alpha_{2}$-macroglobulin is age-dependent, with the concentration in cord blood varying between 2 and $4 \mathrm{~g} / \mathrm{l}$, which is $50 \%$ higher than the normal mean adult level. ${ }^{12}$ The Down's syndrome patients, mean age 40 years, were found to have a $\frac{\mathbb{D}}{\overparen{D}}$ higher quantity of $\alpha_{2}-\mathrm{MG}$ which is in keeping with $\stackrel{?}{?}$

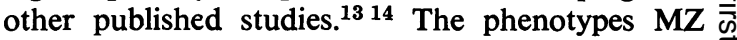
and MS did show differences from that of MM (table 3) and the SS phenotypes exhibited $\alpha_{2}-\mathrm{MG}$ 듬 levels similar to those of MS and MZ. In both क newborn infants and Down's syndrome patients, the $\mathbb{\Phi}$ MS phenotype was lower in $\alpha_{2}$-macroglobulin con-

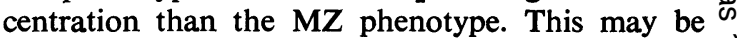
the result of sample size effect, as the number of $\vec{O}$ subjects in both the MS and MZ classes are small $\overrightarrow{\vec{\omega}}$ compared to the number in the MM classes. Since $\vec{\omega}$ the frequency of $\mathrm{ZZ}$ phenotypes is very low among normal populations, we had no access to them among these patients and controls, so we used $\mathrm{Pi}_{\mathbf{z}} \overrightarrow{\vec{v}}$ homozygotes obtained from liver disease patients. $\dot{\omega}$

It is of interest to note that among $\mathrm{ZZ}$ phenotypes $\vec{\nabla}$ with liver disease the $\alpha_{2}-\mathrm{MG}$ level is considerably lower. This reduction is unlikely to be attributed to 5 liver disease since $\alpha_{2}-\mathrm{MG}$ levels are reported to be $\overrightarrow{\vec{c}}$ raised among liver disease patients. ${ }^{15}$ The biological $\subsetneq$ significance is, however, not clear at the moment. $\mathbb{D}$ Twumasi et al $^{16}$ have suggested that increased $\overrightarrow{0}$ complexing of $\alpha_{2}-\mathrm{MG}$ to elastase in ZZ patients ${ }^{\circ}$ could exacerbate the tissue destruction by elastase. Although the proof is inconclusive, these trends suggest the possibility of interrelated regulations of antiproteases in the normal, and deviations in this balance between antiproteases and proteases could $\frac{\circ}{\varnothing}$ lead to disease. Future experimental work is designed to test some of these possibilities.

\section{References}

1 Aarskog D, Fagerhol MK. Protease inhibitor (Pi) phenotypes in chromosome aberrations. $J$ Med Genet 1970; 7:367-70.

2 Kueppers F, O'Brien P, Passarge E, Rüdiger HW. Alpha $_{1}$-antitrypsin phenotypes in sex chromosome mosaicism. J Med Genet 1975;12:263-4.

3 Fineman RM, Kidd KK, Johnson AM, Breg WR. Increased frequency of heterozygotes for $a_{1}$-antitrypsin 을 variants in individuals with either sex chromosome mosaicism or trisomy. Nature 1976;260:320-1.

4 Arnaud P, Burdash NM, Wilson GB, Fudenberg HH. 을 Alpha-1-antitrypsin (Pi) types in Down's syndrome. No
Clin Genet 1976;10:239-43.

5 Kueppers F. Determination of $a_{1}$-antitrypsin pheno- $N$ types by isoelectric focusing in polyacrylamide gels. J Lab Clin Med 1976;88:151-5.

- Ball JRB, Brackenridge CJ, McKay H, Pitt DB. Haptoglobin distributions in Down's syndrome. Clin Genet $1972 ; 3: 334-40$.

7 Brackenridge CJ, Pitt DB, Sheehy AJ. The distributions of seven genetic polymorphisms in patients with Down's ? syndrome. Clin Genet 1974;5:414-9.

${ }^{8}$ Cook P. The genetics of alpha-1-antitrypsin: a family $\bar{O}$ study in England and Scotland. Ann Hum Genet 1975; $\mathbb{D}$ 38:275-86.

9 Rynbrandt DJ, Ihrig J, Kleinerman J, et al. Serum trypsin inhibitory capacity and Pi phenotypes. Am J Clin Pathol $1975 ; 63: 251-60$. 
10 Hamerton JL. Human cytogenetics. vol 2. New York: Academic Press, 1971:197-200.

11 Evans HE, Bognacki NS, Perrott LM, Glass L. Prevalence of alpha-1-antitrypsin Pi types among newborn infants of ethnic backgrounds. J Pediatr 1977;90:621-4.

12 Laurell CB, Jeppson JO. In: Putnam FW, ed. The plasma proteins: structure, function and genetic control. 2nd ed, vol 1. New York: Academic Press, 1975:246-57.

13 James K, Johnson G, Fudenberg HH. The quantitative estimation of $\alpha_{2}$-macroglobulin in normal, pathological and cord sera. Clin Chim Acta 1966;14:207-14.

14 Heinburger N. Biochemistry of protease inhibitor from human plasma. A review of recent developments. Bayer Symposium V. Protease Inhibitors 1974:14-22.

15 Harpel PC. Human alpha-2-macroglobulin. In: Colowich, ed. Methods in enzymology. vol 44. Proteolytic enzymes. New York: Academic Press, 1976:639-52.

16 Twumasi DI, Liener IE, Galdston M, Levytska V. Activation of human leukocyte elastase of human $\alpha_{2}-$ macroglobulin. Nature 1977;267:61-3.

Requests for reprints to Miss H McPhee, Department of Genetics, University of Melbourne, Parkville, Victoria 3052, Australia. 